\title{
Gender Differences in NCAA Non-Revenue Sports: An Examination of Men's and Women's Soccer Coaching Salaries
}

\author{
David Eaton \\ Murray State University, deaton@murraystate.edu \\ Martin Milkman \\ Murray State University, mmilkman@murraystate.edu
}

Follow this and additional works at: https://digitalcommons.murraystate.edu/faculty

Part of the Economics Commons

\section{Recommended Citation}

Eaton, David and Milkman, Martin, "Gender Differences in NCAA Non-Revenue Sports: An Examination of Men's and Women's Soccer Coaching Salaries" (2021). Faculty \& Staff Research and Creative Activity. 87. https://digitalcommons.murraystate.edu/faculty/87

This Non-Peer Reviewed Publication is brought to you for free and open access by Murray State's Digital Commons. It has been accepted for inclusion in Faculty \& Staff Research and Creative Activity by an authorized administrator of Murray State's Digital Commons. For more information, please contact msu.digitalcommons@murraystate.edu. 
Gender Differences in NCAA Non-Revenue Sports: An Examination of Men's and Women's Soccer Coaching Salaries

David H. Eaton and Martin I. Milkman*

\begin{abstract}
:
This paper examines the determinants of head coaching salaries in men's and women's collegiate soccer. Both of these sports are considered non-revenue sports, and thus differences in sports revenues should not impact coaching salaries. We analyze salaries of head coaches in these sports to determine if i) coaches in women's soccer earn systematically less than coaches of men's soccer, and ii) whether there is a difference in salaries between male and female coaches of women's soccer. We find that salaries for coaches of women's soccer are lower than those for men's soccer. We also find that there is no statistically significant difference in the earnings between male and female coaches of women's soccer. We use financial data from public, Division 1 universities to examine this issue. As found in previous literature on basketball and football coaching salaries, coaching salaries are primarily determined by the size of the University athletic budget and the proportion of resources dedicated to the sport.
\end{abstract}

Key Words: NCAA, Coaching Salaries, Discrimination, Gender Differences, Soccer

* Eaton, Professor of Economics and Interim Dean, Arthur J. Bauernfeind College of Business, Murray State University. Milkman, Professor of Economics, Murray State University. 

Gender Differences in NCAA Non-Revenue Sports: An Examination of Men's and Women's Soccer Coaching Salaries

Often, the highest paid employees of a public university are the football and men's basketball coaches. ESPN reported that in 2017, a men's basketball or football coach was the highest paid state employee in 39 of the 50 U.S. states (ESPN, 2018). Additionally, the coaches of the four teams which played in the 2017 College Football Championship collectively earned $\$ 25.5$ million while the Governors of the 50 states collectively earned $\$ 6.3$ million. While there is no corresponding women's sport to football, most universities do have a women's basketball program. In most cases, the men's basketball coach is paid significantly more than the women's basketball coach.

While it is possible that these salary differences between men's and women's basketball coaches are based on discrimination, it is also true that men's basketball programs, in general, bring in significantly more revenue to the athletic programs than do women's basketball. With this being the case, and if salary is commensurate with revenue contributions from the program, then we would expect that the men's basketball coach would earn more than the women's basketball coach. As an example, according to NCAA statistics for the 2016-17 season, average attendance at men's basketball games was 4,799 compared to only 1,586 for women's games (NCAA (b), NCAA (d)). Television broadcast rights also favor men's basketball. Currently, the NCAA and CBS/Turner are in the midst of a 14-year, roughly \$11 billion contract for the NCAA men's basketball tournament (Kim, 2017). When that deal concludes, a new 8-year, $\$ 8.8$ billion agreement will commence. In contrast, the women's basketball tournament is part of a 24- 
championship package with ESPN (Reynolds, 2018). This package is valued at \$500 million over the 14 years through the 2023-24 academic year.

\section{Literature Review}

In part because of its visibility, coaching compensation in football and men's basketball has been the subject of numerous academic works. These papers typically use a fairly common set of independent variables and seek to estimate the determinants of college coaching salaries. These variables include measures of work experience and job performance, as well as institutional characteristics including athletic budgets and revenues. Most also include some measure of sport-specific revenue both as a measure of ability to pay, and as a measure of the value of marginal product for coaches of a particular sport. Demographic information about coaches is also included.

In an early paper in this literature, Humphreys (2000) examined pay differences between men's and women's basketball coaches using data from 238 Division I universities which offered both men's and women's basketball during the 1990-91 basketball season. Not surprisingly, he found that coaches of men's basketball teams earn more than coaches of women's basketball teams. In fact, his estimates suggest that coaches of women's basketball teams earn between $52-57 \%$ of what coaches of men's basketball teams earn. What was interesting in Humphreys' results, however, was that among women's basketball coaches, female coaches earned a 7-9\% premium over male coaches. Brock and Foster (2010) re-examined the salary differences between men and women's basketball coaches at 161 Division I schools and found no evidence of gender related salary differences between men and women coaching women's basketball during the 
2004-05 season. Traugutt et al. (2018) used data from 36 Power 5 conference members and found that revenue-related factors were the prime factors explaining compensation. ${ }^{1}$ Additionally, they found no significant differences in the salaries of male and female coaches in women's basketball.

Brewer, McEvoy, and Popp (2015) used compensation data from coaches' contracts gathered by Winthrop Intelligence to estimate basketball coaching salaries for 193 Division I men's basketball programs for 2012. They found that basketball program revenues and measures of coaching success account for most of the salary level of the coaches. Grant, Leadley and Zygmont (2013) examined salary determinants for coaches in the Football Bowl Subdivision and found that measures of coaching success and measures of athletic department size were primary determinants of coaches' salaries. Byrd, Mixon, and Wright (2013); Fogarty, Soebbing, and Agyemang (2015); Inoue, Plehn-Dujowich, Kent, and Swanson (2012); and Mirabile and Witte (2014) provide similar results.

A common theme among this literature is that the two primary determinants of coaching salaries are coaching success and the size of the athletic department budget, with the size of the budget typically being the most important factor. These results are derived from coaching contracts and performance in Division I college football and Division I college basketball.

This paper explores the topic of coaching salaries from a unique perspective. For most universities, football and men's basketball are the primary revenue sports. While other teams may bring in some relatively small amount of revenue, they are traditionally considered "nonrevenue" and funded by monies earned by football, basketball, and transfers from the host

\footnotetext{
${ }^{1}$ (Power 5 schools are those affiliated with the Atlantic Coast, Big Ten, Big Twelve, Southeastern, and Pac 12 conferences).
} 
institution, including student fees. In a situation like this, we may expect similar non-revenue sports to compensate coaches of men's teams and women's teams more equitably. To determine if this is the case we examine the determinants of coaching salaries for men's and women's soccer. We examine if there are systematic differences in pay between head coaches in the men's sport and head coaches in the women's sport. We also examine whether female and male coaches of women's sports earn systematically different amounts.

\section{Research Questions}

RQ1: What factors determine the salary of NCAA soccer coaches?

RQ2: Are there systematic differences between salaries paid to coaches of men's soccer teams and those paid to coaches of women's soccer teams?

RQ3: Are there systematic differences between salaries paid to male and female coaches of women's soccer teams?

\section{A model for coaching salaries}

We estimate a model to explain head coach salaries in non-revenue sports that follows closely the models used in the literature to estimate coaching salaries in football and basketball. We chose men's and women's soccer as complementary non-revenue sports. There are two primary reasons why we chose these sports. First, the sports can be seen as roughly similar in rules and strategy on the men's and women's side. Second, while other sports such as golf, track, swimming, etc. have participation by both men and women, and in some cases have women 
coaching men's teams, it is difficult to identify a straightforward measure of coaching success for these sports. For soccer, games won and lost provide clear measures of success

Following previous literature, our salary model is given by:

$$
\begin{array}{r}
\operatorname{Ln}(\text { Coaching salary })=\mathrm{C}+\boldsymbol{\alpha}(\text { coach characteristics })+\boldsymbol{\beta}(\text { school characteristics }) \\
+\gamma(\text { sport characteristics })+\delta(\text { sport })+\zeta(\text { female })+v .
\end{array}
$$

Here, coach characteristics represent the success of the coach as measured by career winning percentage, and the experience of the coach as measured by the number of years of head coaching experience. As mentioned above, previous literature suggests that coaching success is an important determinant of coaching salary.

School characteristics include measures of conference affiliation as well as department revenues and expenses. A common finding of the previously cited papers is that schools with larger athletic department budgets pay more in salary than schools with smaller budgets, and we test this as well. We add controls for conference primarily to distinguish schools in the Power 5 conferences from the rest as Power 5 schools tend to spend far more resources on athletics than other schools. Power 5 schools are those affiliated with the Atlantic Coast, Big Ten, Big Twelve, Southeastern, and Pac 12 conferences.

Sport characteristics include measures of revenue for particular sports, represented primarily by ticket revenue for the sport. We also look at measures of sport profitability and the importance of the sport to the school as measured by the amount of athletic expenses dedicated to that particular sport. Also included are measures of the number of female coaches and female sports offered by the University. While offering women's sports is often a way to comply with Title IX restrictions, the choice to hire women as coaches of women's sports teams, and the number of 
women's sports offered, may serve as a proxy for the school's commitment to women's athletics. Welch and Sigelman (2007) found that women are more likely to occupy coaching positions at schools which devoted more resources to women's sports. We will use the number of women's sports offered and the number of female coaches as measures for a school's commitment to women's athletics.

Two variables are used to examine if male sports (and coaches) are treated differently than female sports (and coaches). The first dummy variable is "women" which will take a value of ' 1 ' for observations on women's soccer. If coaches of men's and women's soccer are treated in the same manner, this dummy variable should be statistically insignificant.

The second dummy variable will take on a value of ' 1 ' if a women's soccer coach is female. This allows us to measure whether male and female coaches are treated in a similar manner within a sport with both male and female head coaches. Since there are no females coaching men's soccer, this analysis will only be done on salary equations for women's soccer.

\section{Data and Summary Statistics:}

The data for this project was collected by the Chronicle of Higher Education and the Huffington Post as part of their report on college sports subsidies. The publications collected NCAA financial reports and EADA reports from a large number of public, Division I, Universities. These forms contain detailed financial records including salaries paid to coaches as well as other revenue and expense categories. We were able to access the data at http://projects.huffingtonpost.com/projects/ncaa/subsidy-scorecards. 
We used financial data for fiscal year 2014. Unfortunately, our desired information was not available for all Universities. In particular, private Universities are not included as they are not required to disclose information in the same manner as public universities. Additionally, some of the data on the site was incomplete for particular schools leading us to omit those schools from our final data set. In total, we have usable information on 73 men's soccer programs, and 148 women's soccer programs. As a point of reference, the NCAA reported that in the 2013 season there were 204 Division 1 men's soccer teams and 322 Division 1 women's soccer teams (NCAA (c)).

In addition to salary information, we collected data on department revenue and expenses, as well as sport-specific revenues and expenses. All salary and financial information was for the 2014 reporting year.

Information on coaching records was gleaned from the NCAA web site. Coaching records and years coached were based on coaching careers through the 2012-13 seasons, one year prior to the financial information. This is done to recognize that the current salary of a coach is dependent upon coaching records prior to that year. We also have a dummy variable indicating if the coach was female. As noted earlier, female coaches were only present in women's soccer.

We also identified the conference affiliation of each school during the 2012-13 season for which coaching records were obtained. From this we created a dummy variable representing whether the school was a member of one of the so-called "power 5" conferences. Power 5 conferences are: Atlantic Coast, Big Ten, Big Twelve, Southeastern, and Pac Twelve. In general, these schools spend far more on athletics of all varieties than schools in other conferences. 
Table 1 provides summary statistics on key variables for each of the sports examined. The table provides these statistics for the entire sample, as well as broken out by power 5 and non-power 5 conferences. As expected, in comparison to non-power 5 schools, power 5 conferences have higher athletic budgets, earn higher levels of ticket revenue from these sports, but spend a lower percentage of their athletic budget on soccer.

There are 73 observations on men's soccer. Coaching salaries average $\$ 135,437$ (\$105,937 median). Average expenditure on men’s soccer is $\$ 763,298$ (\$620,439 median) while average revenue is $\$ 334,985$ ( $\$ 261,530$ median). On average, soccer coaches have 13.6 years of head coaching experience. There are fewer observations on men's soccer in part because fewer schools offer men's soccer. Additionally, a larger proportion of schools offering men's soccer at the Division I level are private schools.

There are 148 observations on women's soccer. Coaching salaries average $\$ 116,248$ (\$93,685 median). Of women's soccer coaches, $22 \%$ of coaches are female, this is true both overall and in the Power 5 conferences. The average school spends $\$ 876,822$ on women's soccer $(\$ 725,493$ median). On average, women's soccer programs bring in $\$ 380,793$ in revenue $(\$ 311,268$ median). Women's soccer coaches have, on average, 12.4 years of experience as head coaches. We performed a simple t-test on the difference between coach salaries for men's soccer and coach salaries for women's soccer and found no statistically significant difference in coaching salaries between the two sports. Additionally, we performed a simple t-test on the difference between male coaches of women's soccer programs and female coaches of women's soccer programs and again found no statistically significant difference. We will return to this discussion in the results section. 
What is also obvious from Table 1 is that the power 5 schools play, pun intended, in a different league financially than the other schools. Clearly any examination of salaries must account for the impact of a power 5 conference. What seems to be the case, however, is that the revenue available for higher spending on soccer in power five conferences is not coming from these sports. It would seem that higher athletic department budgets, driven largely by the revenue sports, increase salaries, and other expenditures, on all sports.

Indeed, it may be the case in soccer that department spending may be the primary driver of salary differences. In the full data set, the correlation between head coaching salaries and department expenses is .61. Higher spending on a particular sport (net of head coach's salary) has a .85 correlation with head coach salary.

While soccer is considered "non-revenue," a number of programs do report some ticket revenue, but, the amounts are very small. In our sample, Texas A\&M receives the most ticket revenue from women's soccer $(\$ 258,768)$. The University of Akron reports men's soccer ticket revenue of $\$ 118,835$. In general, most schools don't earn significant amounts of revenue from ticket sales for soccer. Of the 221 total observations across both sports, 137 claim $\$ 0$ in ticket revenue, and 178 claim less than $\$ 10,000$ in ticket revenue.

The primary expenses for these sports are the scholarship dollars used for the student athletes. The maximum number of scholarships a sport can offer is set by the NCAA. Men's soccer is allocated 9.9 scholarships while women's soccer has 14 . Neither of these are headcount sports and thus teams are able to offer partial scholarships to student-athletes so long as they do not exceed these caps. Teams may not use all of their allotted scholarships due to smaller athletic budgets or other University or NCAA imposed restrictions. 
On average, $2.8 \%$ of an athletic department's budget is spent on men's soccer, compared to roughly $3 \%$ for women's soccer. The variable used in the estimations for the share of soccer expenses is net of the soccer head coach's salary.

In general, few of these sports generate a profit for their school. Overall, 25 programs (11.3\%) reported a profit in the 2014 fiscal year. On average, those programs which earn a profit earn $\$ 51,524$, with a median profit of $\$ 14,181$. For programs with a loss, the average loss is $\$ 582,238$, with a median loss of $\$ 476,422$.

\section{Results and Discussion:}

Table 2 presents the results of a model of coach salaries including results for both men's and women's soccer. The models were estimated using ordinary least squares with a heteroskedastcity consistent variance/covariance matrix. Column one provides results for all schools, column two for power five conference schools, and column three for non-power 5 conference schools.

The results are similar in all models estimated. A coach's total win percentage, the size of the department budget, and the share of the department budget allocated to the sport (net of coach salaries) all positively impact the salary of the head coach. An increase in a coach's winning percentage from .500 to .600 leads to a $4.3 \%$ increase in the coach's salary. For non-power 5 schools we see a $4.45 \%$ salary increase for this change in winning percentage. The estimated impact is higher for power 5 schools at $4.71 \%$, but this result is not statistically significant. It should be noted that we also ran models using a coach's winning percentage at their current school and found qualitatively similar results. 
Examining the results on department expenses, a one-percent increase in department budgets increase coaching salaries in soccer by roughly $.66 \%$. While this coefficient also varies between power 5 and non-power 5 conferences, the difference is of much smaller magnitude than the impact of winning percentages on salaries, and is smaller for power 5 schools than for non-power 5 schools. Additionally, the greater the proportion of athletic spending on a sport, the higher the coach's salary. In the overall model, a one percentage point increase in sport spending (net of coach salary) leads to a $17.7 \%$ increase in coach's salaries. Once again, the impacts are larger for power 5 schools than non-power 5 , and are quite pronounced.

In all the estimations, coaches of women's soccer earn significantly less than coaches of men's soccer. This is in contrast to what the simple t-test suggested earlier. Overall, women's soccer coaches earn roughly 13.5 percent less than men's soccer coaches. For Power 5 schools the gap increases to $24 \%$. In non-Power 5 schools, this gap is $12.2 \%$. To determine if the impact of other right hand side variables on coaches' salaries for men's and women's soccer, we estimated models using interaction terms with women's soccer and the other right-hand side variables, but Wald tests failed to reject a null hypothesis of zero impact from the collected set of interaction terms.

We have added a cross product term that indicates whether the coach of a women's soccer team is male or female. Across all equations the coefficient on this variable is statistically insignificant. This would indicate that there is no systematic difference in salary between male and female coaches in women's sports. We will revisit this in the next table.

It is reasonable to suggest that the salary function may vary between men's and women's soccer. Tables 3 and 4 present results (heteroskedasticity corrected) separately for men's and women's soccer. We again estimate models for all schools, power 5 schools only, and non-power 5 
schools. It should be noted that we only have 18 observations for men's soccer teams in Power 5 conferences and thus any results from this regression should be viewed as quite tentative. Total winning percentage is statistically significant only in women's soccer. A $10 \%$ increase in department spending on sports leads to between an $8.1 \%$ increase in salaries for men's soccer coaches and a $6 \%$ increase for coaches of women's soccer. For men, the impact of an increase in athletic department spending is not significant. For women, this variable is significant across all three estimations.

As before, the larger the share of department expenses spent on a particular sport (a measure of the sport's importance to the school) the higher the coach's salary. For men's soccer a one percentage point increase in the share of department spending, net of the coach's salary, would translate to a roughly $24 \%$ increase in salary. The impact for Power 5 schools is roughly 5 times as great, but again, the small sample size serves to reduce our confidence in this result. The same increase in the share of department spending would lead to a $14.5 \%$ increase in the salary of a women's soccer coach. This, too, is higher in Power 5 departments, with Power 5 soccer coaches seeing a $21.7 \%$ increase for each percentage point increase in department expenditures (net of head coaches' salary) on women's soccer.

We find no statistically significant difference between the salaries of male head coaches and female head coaches within women's soccer.

In none of our specifications do we find that either the number of women's teams at a school, nor the number of women's coaches, has a statistically significant impact on coaching salaries. 


\section{Conclusion:}

Numerous papers have examined the determinants of college coaching salaries using data from basketball and football. The primary result found is that coaching salaries are best explained by the school's athletics budget, and the success of the coach as measured by won/loss percentage. This paper extends the examination of college coaching salaries from the revenue sports of basketball and football to the non-revenue sports of women's and men's soccer. As with previous literature based on revenue sports, we find that coaching salaries are positively affected by the success of the coach and the size of the athletic department budget.

We do find a few systematic differences in salaries between men's and women's soccer. Men's soccer coaches earn, on average, thirteen percent more than women's soccer coaches. This is true even though women's soccer, on average, makes up a larger share of athletic department budgets. (It should be noted, though, that the larger scholarship allocation for women's soccer contributes to the higher expenditures for that sport).

Previous literature has found that larger athletic budgets lead to higher salaries for coaches. We find this as well. In particular we find that increases in the size of athletic budgets translate into a roughly $30 \%$ larger increases in coaching salaries in men's soccer than in women's soccer. Additionally, we found that larger shares of athletic spending on soccer leads to higher salaries for soccer coaches with the impact the coaches of men's soccer programs being greater than the impact in women's soccer programs.

Finally, we do not find any statistical evidence of differences in salaries for male and female coaches in women's soccer. So, while the results of this paper do provide evidence consistent with the belief that coaches of men's soccer programs earn systematically more than coaches of 
women's soccer programs, the results do not find evidence consistent with the belief that male coaches and female coaches are paid differently within women's soccer programs. 


\section{References:}

Brewer, R. M., McEvoy, C. D., \& Popp, N. (2015). Predicting intrinsic value of NCAA division I men's basketball coaching salaries. Journal of Issues in Intercollegiate Athletics. 8, 74-91.

Brock, S. L., \& Foster, S. (2010). Does gender affect compensation among NCAA basketball coaches? International Journal of Sport Finance, 5(2), 96-106.

Byrd, W. J., Mixon, P. A., \& Wright, A. (2013). Compensation of college football's head coaches: A case study in firm size's effects on pay. International Journal of Sport Finance, 8(), 224-235.

ESPN, 2018. Who's the Highest Paid Person in Your State? Retrieved from:

http://www.espn.com/espn/feature/story/_id/22454170/highest-paid-state-employees-includencaa-coaches-nick-saban-john-calipari-dabo-swinney-bill-self-bob-huggins .

Fogarty, K., Soebbing, B. P., \& Agyemang, K. J..A. (2015). NCAA division I-FBS salary determinants: A look at new and amended contracts. Journal of Issues in Intercollegiate Athletics, 8, 123-138.

Grant, R. R., Leadley, J. C., \& Zygmont, Z. X. (2013). Just win baby? Determinants of NCAA football bowl subdivision coaching compensation. International Journal of Sport Finance, 9(1), 61-74.7

Huffington Post. (2015). Subsidy scorecard. Retrieved from http://projects.huffingtonpost.com/projects/ncaa/subsidy-scorecards.

Humphreys, B. R. (2000). Equal pay on the hardwood: The earnings gap between male and female NCAA division I basketball coaches. Journal of Sports Economics, 1(6), 299-307.

Inoue, Y., Plehn-Dujowich, J. M., Kent, A., \& Swanson, S. (2012). Roles of performance and human capital in college football coaches' compensation. Journal of Sport Management, 27, 7383.

Kim, Joshua. March 20, 2017. 19.6 Billion EdTech Lessons From the NCAA March Madness TV Contract. Inside Higher Ed. https://www.insidehighered.com/blogs/technology-andlearning/196-billion-edtech-lessons-ncaa-march-madness-tv-contract

Mirabile, M. P., \& Witte, M. D. (2014). Can schools buy success in college football? Coach compensation, expenditures and performance. Journal of Research in Educational Sciences, 5(7), 5-19.

National Collegiate Athletic Association (a). Archived Team-By-Team Final Statistics. Retrieved from http://web1.ncaa.org/stats/StatsSrv/careersearch.

National Collegiate Athletic Association (b). 2017 NCAA Men's Basketball Attendance. Retrieved from http://fs.ncaa.org/Docs/stats/m_basketball_RB/Reports/attend/2017.pdf. 
National Collegiate Athletic Association (c). NCAA Sports Sponsorship and Participation Rates Database. Retrieved from http://www.ncaa.org/about/resources/research/ncaa-sports-sponsorshipand-participation-rates-database.

National Collegiate Athletic Association (d). 2017 NCAA Women's Basketball Attendance. Retrieved from http://fs.ncaa.org/Docs/stats/w_basketball_RB/reports/Attend/2017.pdf.

Reynolds, Mike. March 29, 2018. ESPN Expands NCAA Championships Rights via $\$ 500$ Million Deal. https://www.multichannel.com/news/espn-expands-ncaa-championships-rights-500$\underline{\text { million-deal-298185 }}$

Traugutt, A., N. Sellars, \& A.L. Morse. (2018). Salary Disparities Between Male and Female Head Coaches: An Investigation of the NCAA Power Five Conferences. The Journal of SPORT, $6(1)$, article 4. 
Table 1: Summary Statistics by Sport:

a) Men's Soccer

Variable

All Coaches: $n=73$

Head Coach Salary

Department Expenses

Department Revenues

Sport Expenses

Sport Revenues

Sport Ticket Sales

Sport Share of budget

Years of Head Coaching Experience

Winning pct.
Mean

135,437

$39,396,041$

$40,265,802$

763,298

334,985

10,741

$2.8 \%$

13.6

.553

Median

High

Low

Power 5 Conferences: $\mathrm{n}=18$

Head Coach Salary

Department Expenses

Department Revenues

Sport Expenses

Sport Revenues

Sport Ticket Sales

Sport Share of budget

Years of Head Coaching

Winning pct. Experience
Non Power 5 Conferences: $\mathrm{n}=55$

Head Coach Salary
Department Expenses

Department Revenues

Sport Expenses

Sport Revenues

Sport Ticket Sales

Sport Share of budget

Years of Head Coaching Experience

Winning pct.

$\begin{array}{ll}225,761 & 201,760 \\ 91,052,377 & 86,261,959 \\ 89,675,775 & 85,099,347 \\ 1,218,964 & 1,194,270 \\ 379,091 & 342,570 \\ 20,349 & 13,626 \\ 1.4 \% & 1.4 \% \\ 12.9 & 10.5\end{array}$

.637

$$
105,937
$$

$26,934,534$

$16,799,800$

620,439

261,530

3,433

$2.3 \%$

12

.555
576,273

$145,000,000$

$158,000,000$

$2,278,739$

$1,395,048$

106,111

$8.4 \%$

37

.860
20,250

$6,324,972$

$6,340,084$

266,888

1,500

0

$0.8 \%$

1

0
576,273

$145,000,000$

$158,000,000$

$2,278,739$

977,481

63,987

$2.2 \%$

36

.860
111,147

$64,924,362$

$8,468,779$

803,600

51,192

0

$0.8 \%$

1

.400

$\begin{array}{llll}105,877 & 91,310 & 368,285 & 20,250 \\ 22,490,331 & 19,020,977 & 71,396,255 & 6,324,972 \\ 22,709,811 & 18,929,350 & 71,519,433 & 6,340,084 \\ 614,171 & 557,160 & 1,901,083 & 266,888 \\ 320,550 & 234,019 & 1,395,048 & 1,500 \\ 7,597 & 2,485 & 106,111 & 0 \\ 3.2 \% & 3.1 \% & 8.4 \% & 1.2 \% \\ & & & \\ 13.8 & 13 & 37 & 1 \\ .527 & .541 & .860 & 0\end{array}$


b) Women's Soccer

Variable

All Coaches: $\mathrm{n}=148$

Head Coach Salary

Department Expenses

Department Revenues

Sport Expenses

Sport Revenues

Sport Ticket Sales

Sport Share of budget

Years of Head Coaching

Experience

Winning pct.

Power 5 Conferences: $\mathrm{n}=40$
Mean

116,248
$40,231,794$
$41,168,075$
876,822
380,793

7,106

$3.0 \%$

12.4

.536
Median

High

Low

93,685
$25,476,388$
$25,042,807$
725,493
311,268

1,519

$2.8 \%$

13

.550

$\begin{array}{ll}455,458 & 14,520 \\ 145,000,000 & 3,952,319 \\ 158,000,000 & 3,952,319 \\ 3,916,867 & 170,363 \\ 2,342,818 & 0 \\ 258,768 & 0 \\ 7.6 \% & 0.9 \%\end{array}$

34

.938
0

0

\begin{tabular}{|c|c|c|c|c|}
\hline Head Coach Salary & 190,814 & 174,474 & 455,458 & 102,500 \\
\hline Department Expenses & $92,451,421$ & $89,115,493$ & $145,000,000$ & $55,051,905$ \\
\hline Department Revenues & $95,680,708$ & $95,741,591$ & $158,000,000$ & $54,426,818$ \\
\hline Sport Expenses & $1,511,372$ & $1,386,516$ & $3,916,867$ & 967,073 \\
\hline Sport Revenues & 452,674 & 294,139 & $2,342,818$ & 4,783 \\
\hline Sport Ticket Sales & 20,084 & 5,424 & 258,768 & 0 \\
\hline Sport Share of budget & $1.7 \%$ & $1.5 \%$ & $4.1 \%$ & $0.9 \%$ \\
\hline \multicolumn{5}{|l|}{ Years of Head Coaching } \\
\hline Experience & 14.2 & 16 & 34 & 0 \\
\hline Winning pet. & .609 & .601 & .938 & 0 \\
\hline \multicolumn{5}{|c|}{ Non Power 5 Conferences: $\mathrm{n}=108$} \\
\hline Head Coach Salary & 88,631 & 84,003 & 236,835 & 14,520 \\
\hline Department Expenses & $20,891,191$ & $18,115,394$ & $71,396,255$ & $3,952,319$ \\
\hline Department Revenues & $20,978,210$ & $17,930,218$ & $71,519,433$ & $3,952,319$ \\
\hline Sport Expenses & 641,803 & 629,652 & $1,467,943$ & 170,363 \\
\hline Sport Revenues & 354,171 & 318,250 & $1,504,045$ & 0 \\
\hline Sport Ticket Sales & 2,299 & 659 & 24,574 & 0 \\
\hline Sport Share of budget & $3.5 \%$ & $3.3 \%$ & $7.6 \%$ & $1.4 \%$ \\
\hline \multicolumn{5}{|l|}{ Years of Head Coaching } \\
\hline Experience & 11.8 & 12 & 34 & 1 \\
\hline Winning pct. & .509 & .520 & .938 & .149 \\
\hline
\end{tabular}


Table 2: A basic model of coaching salary for men's and women's soccer.

Dependent variable: log of head coach salary

t-statistics in parenthses

\begin{tabular}{|c|c|c|c|}
\hline Variable & $\begin{array}{l}\text { All schools } \\
(n=221)\end{array}$ & $\begin{array}{l}\text { Power } 5 \\
\text { Only } \\
(n=58)\end{array}$ & $\begin{array}{l}\text { Non-power } \\
5 \text { only } \\
(n=162)\end{array}$ \\
\hline Constant & $\begin{array}{l}-0.531 \\
(-0.59)\end{array}$ & $\begin{array}{l}0.219 \\
(0.08)\end{array}$ & $\begin{array}{l}-0.456 \\
(-0.30)\end{array}$ \\
\hline $\begin{array}{l}\text { Years of Head } \\
\text { Coaching Experience }\end{array}$ & $\begin{array}{l}0.002 \\
(0.84)\end{array}$ & $\begin{array}{l}0.006 \\
(0.95)\end{array}$ & $\begin{array}{l}0.001 \\
(0.42)\end{array}$ \\
\hline Total Win Pct. & $\begin{array}{l}0.426^{* * * *} \\
(2.84)\end{array}$ & $\begin{array}{l}0.471 \\
(1.27)\end{array}$ & $\begin{array}{l}0.445^{* * * *} \\
(2.64)\end{array}$ \\
\hline $\begin{array}{l}\text { Log of Department } \\
\text { Expenses }\end{array}$ & $\begin{array}{l}0.664 * * * \\
(12.66)\end{array}$ & $\begin{array}{l}0.618 * * * \\
(3.91)\end{array}$ & $\begin{array}{l}0.650 * * * \\
(7.48)\end{array}$ \\
\hline $\begin{array}{l}\text { Number of Female } \\
\text { Coaches }\end{array}$ & $\begin{array}{l}0.003 \\
(0.29)\end{array}$ & $\begin{array}{l}-0.004 \\
(-0.21)\end{array}$ & $\begin{array}{l}0.006 \\
(0.43)\end{array}$ \\
\hline $\begin{array}{l}\text { Number of Female } \\
\text { Teams }\end{array}$ & $\begin{array}{l}-0.001 \\
(-0.01)\end{array}$ & $\begin{array}{l}-0.010 \\
(-0.27)\end{array}$ & $\begin{array}{l}0.017 \\
(0.91)\end{array}$ \\
\hline $\begin{array}{l}\text { Ticket Revenue } \\
\text { (dummy) }\end{array}$ & $\begin{array}{l}0.042 \\
(1.11)\end{array}$ & $\begin{array}{l}0.051 \\
(0.79)\end{array}$ & $\begin{array}{l}0.026 \\
(0.56)\end{array}$ \\
\hline $\begin{array}{l}\text { Sport share of } \\
\text { Dept. expenses }\end{array}$ & $\begin{array}{l}17.72 * * * \\
(5.78)\end{array}$ & $\begin{array}{l}32.53 * * * \\
(2.89)\end{array}$ & $\begin{array}{l}17.13 * * * \\
(5.00)\end{array}$ \\
\hline $\begin{array}{l}\text { Women's Soccer } \\
\text { (dummy) }\end{array}$ & $\begin{array}{l}-0.135 * * * \\
(-2.83)\end{array}$ & $\begin{array}{l}-0.240 * * \\
(-2.46)\end{array}$ & $\begin{array}{l}-0.122 * * \\
(-2.18)\end{array}$ \\
\hline $\begin{array}{l}\text { Women's Soccer } \\
\text { *female }\end{array}$ & $\begin{array}{l}-0.015 \\
(-0.31)\end{array}$ & $\begin{array}{l}-0.040 \\
(-0.37)\end{array}$ & $\begin{array}{l}0.019 \\
(0.38)\end{array}$ \\
\hline $\mathrm{R}^{2}$ & 0.698 & 0.422 & 0.506 \\
\hline
\end{tabular}


Table 3: Men's Coaching Salary Models

Dependent variable: log of head coaches salary t-statistics in parentheses

\begin{tabular}{|c|c|c|c|}
\hline Variable & $\begin{array}{l}\text { All Schools } \\
(n=73)\end{array}$ & $\begin{array}{l}\text { Power } 5 \text { Only } \\
(n=18)\end{array}$ & $\begin{array}{l}\text { Non-Power } 5 \\
(\mathrm{n}=55)\end{array}$ \\
\hline Constant & $\begin{array}{l}-2.914 \\
(-1.63)\end{array}$ & $\begin{array}{l}2.18 \\
(0.21)\end{array}$ & $\begin{array}{l}-2.83 \\
(-0.27)\end{array}$ \\
\hline $\begin{array}{l}\text { Years of Head } \\
\text { Coaching Experience }\end{array}$ & $\begin{array}{l}0.004 \\
(0.97)\end{array}$ & $\begin{array}{l}0.007 \\
(1.24)\end{array}$ & $\begin{array}{l}0.004 \\
(0.92)\end{array}$ \\
\hline Total Win Percentage & $\begin{array}{l}0.336 \\
(1.38)\end{array}$ & $\begin{array}{l}-0.107 \\
(0.89)\end{array}$ & $\begin{array}{l}0.193 \\
(0.73)\end{array}$ \\
\hline $\begin{array}{l}\text { Log of Department } \\
\text { Expenses }\end{array}$ & $\begin{array}{l}0.812 * * * \\
(7.48)\end{array}$ & $\begin{array}{l}0.423 \\
(0.75)\end{array}$ & $\begin{array}{l}0.806 * * * \\
(5.22)\end{array}$ \\
\hline $\begin{array}{l}\text { Number of female } \\
\text { Coaches }\end{array}$ & $\begin{array}{l}0.014 \\
(0.61)\end{array}$ & $\begin{array}{l}0.033 \\
(0.64)\end{array}$ & $\begin{array}{l}0.020 \\
(0.72)\end{array}$ \\
\hline $\begin{array}{l}\text { Number of female } \\
\text { Teams }\end{array}$ & $\begin{array}{l}-0.034 \\
(-1.08)\end{array}$ & $\begin{array}{l}0.047 \\
(0.71)\end{array}$ & $\begin{array}{l}-0.023 \\
(-0.65)\end{array}$ \\
\hline $\begin{array}{l}\text { Ticket Revenue } \\
\text { (dummy) }\end{array}$ & $\begin{array}{l}0.056 \\
(0.69)\end{array}$ & $\begin{array}{l}-0.080 \\
(-0.50)\end{array}$ & $\begin{array}{l}0.031 \\
(0.30)\end{array}$ \\
\hline $\begin{array}{l}\text { Sport share of } \\
\text { Department expenses }\end{array}$ & $\begin{array}{l}23.92 * * * \\
(4.46)\end{array}$ & $\begin{array}{l}115.51 * * * \\
(5.24)\end{array}$ & $\begin{array}{l}23.37 * * * \\
(4.12)\end{array}$ \\
\hline $\mathrm{R}^{2}$ & 0.668 & 0.770 & 0.537 \\
\hline
\end{tabular}

Note: $* * *$ denotes two-tailed significance at the $1 \%$ level, ** denotes two-tailed significance at the 5\% level.

* denotes two-tailed significance at the $10 \%$ level. 
Table 4: Women's Head Coaching Salary Models

Dependent variable: log of head coaches salary t-statistics in parentheses

\begin{tabular}{|c|c|c|c|}
\hline Variable & $\begin{array}{l}\text { All Schools } \\
(n=148)\end{array}$ & $\begin{array}{l}\text { Power } 5 \text { Only } \\
(n=40)\end{array}$ & $\begin{array}{l}\text { Non-Powe } \\
(\mathrm{n}=108)\end{array}$ \\
\hline Constant & $\begin{array}{l}0.407 \\
(0.35)\end{array}$ & $\begin{array}{l}-1.01 \\
(-0.30)\end{array}$ & $\begin{array}{l}0.823 \\
(0.40)\end{array}$ \\
\hline $\begin{array}{l}\text { Years of Head } \\
\text { Coaching Experience }\end{array}$ & $\begin{array}{l}0.001 \\
(0.46)\end{array}$ & $\begin{array}{l}0.007 \\
(0.94)\end{array}$ & $\begin{array}{l}0.001 \\
(0.15)\end{array}$ \\
\hline Total Win Percentage & $\begin{array}{l}0.470 * * \\
(2.49)\end{array}$ & $\begin{array}{l}0.373 \\
(1.01)\end{array}$ & $\begin{array}{l}0.554^{* *} \\
(2.51)\end{array}$ \\
\hline $\begin{array}{l}\text { Log of Department } \\
\text { Expenses }\end{array}$ & $\begin{array}{l}0.600 * * * \\
(9.27)\end{array}$ & $\begin{array}{l}0.694 * * * \\
(3.99)\end{array}$ & $\begin{array}{l}0.562 * * * \\
(4.96)\end{array}$ \\
\hline $\begin{array}{l}\text { Number of female } \\
\text { Coaches }\end{array}$ & $\begin{array}{l}-0.001 \\
(-0.02)\end{array}$ & $\begin{array}{l}-0.007 \\
(-0.27)\end{array}$ & $\begin{array}{l}0.001 \\
(0.07)\end{array}$ \\
\hline $\begin{array}{l}\text { Number of female } \\
\text { Teams }\end{array}$ & $\begin{array}{l}0.012 \\
(0.63)\end{array}$ & $\begin{array}{l}-0.023 \\
(-0.52)\end{array}$ & $\begin{array}{l}0.034 \\
(1.48)\end{array}$ \\
\hline $\begin{array}{l}\text { Ticket Revenue } \\
\text { (dummy) }\end{array}$ & $\begin{array}{l}0.032 \\
(0.74)\end{array}$ & $\begin{array}{l}0.049 \\
(0.60)\end{array}$ & $\begin{array}{l}0.014 \\
(0.25)\end{array}$ \\
\hline $\begin{array}{l}\text { Sport share of } \\
\text { Department expenses }\end{array}$ & $\begin{array}{l}14.48 * * * \\
(3.37)\end{array}$ & $\begin{array}{l}21.69^{*} \\
(1.98)\end{array}$ & $\begin{array}{l}13.64 * * * \\
(2.82)\end{array}$ \\
\hline Female & $\begin{array}{l}-0.017 \\
(-0.36)\end{array}$ & $\begin{array}{l}-0.074 \\
(-0.71)\end{array}$ & $\begin{array}{l}0.023 \\
(0.44)\end{array}$ \\
\hline $\mathrm{R}^{2}$ & 0.723 & 0.439 & 0.495 \\
\hline
\end{tabular}

